\title{
Scotland's forgotten carbon: a national assessment of mid-latitude fjord sedimentary carbon stocks
}

\author{
Craig Smeaton ${ }^{1}$, William E. N. Austin ${ }^{1,2}$, Althea L. Davies ${ }^{1}$, Agnes Baltzer ${ }^{3}$, John A. Howe ${ }^{2}$, and John M. Baxter \\ ${ }^{1}$ School of Geography \& Geosciences, University of St Andrews, St Andrews, KY16 9AL, UK \\ ${ }^{2}$ Scottish Association for Marine Science, Scottish Marine Institute, Oban, PA37 1QA, UK \\ ${ }^{3}$ Institut de Géographie et d'Aménagement Régional de l'Université de Nantes, BP 8122744312 Nantes CEDEX 3, France \\ ${ }^{4}$ Scottish Natural Heritage, Silvan House, Edinburgh, EH12 7AT, UK
}

Correspondence: Craig Smeaton (cs244@st-andrews.ac.uk)

Received: 23 August 2017 - Discussion started: 25 August 2017

Revised: 2 November 2017 - Accepted: 7 November 2017 - Published: 15 December 2017

\begin{abstract}
Fjords are recognised as hotspots for the burial and long-term storage of carbon $(\mathrm{C})$ and potentially provide a significant climate regulation service over multiple timescales. Understanding the magnitude of marine sedimentary C stores and the processes which govern their development is fundamental to understanding the role of the coastal ocean in the global $\mathrm{C}$ cycle. In this study, we use the mid-latitude fjords of Scotland as a natural laboratory to further develop methods to quantify these marine sedimentary $\mathrm{C}$ stores on both the individual fjord and national scale. Targeted geophysical and geochemical analysis has allowed the quantification of sedimentary $\mathrm{C}$ stocks for a number of mid-latitude fjords and, coupled with upscaling techniques based on fjord classification, has generated the first full national sedimentary $\mathrm{C}$ inventory for a fjordic system. The sediments within these mid-latitude fjords hold $640.7 \pm 46 \mathrm{Mt}$ of $\mathrm{C}$ split between $295.6 \pm 52$ and $345.1 \pm 39 \mathrm{Mt}$ of organic and inorganic $\mathrm{C}$, respectively. When compared, these marine mid-latitude sedimentary $\mathrm{C}$ stores are of similar magnitude to their terrestrial equivalents, with the exception of the Scottish peatlands, which hold significantly more C. However, when areanormalised comparisons are made, these mid-latitude fjords are significantly more effective as $\mathrm{C}$ stores than their terrestrial counterparts, including Scottish peatlands. The $\mathrm{C}$ held within Scotland's coastal marine sediments has been largely overlooked as a significant component of the nation's natural capital; such coastal C stores are likely to be key to understanding and constraining improved global $\mathrm{C}$ budgets.
\end{abstract}

Highlights

- Scottish fjords are a more effective store of $\mathrm{C}$ than the terrestrial environment.

- A total of $640.7 \pm 46 \mathrm{Mt}$ of $\mathrm{C}$ is stored in the sediment of Scotland's 111 fjords.

- An estimated $31139-40615 \mathrm{t} \mathrm{yr}^{-1}$ of $\mathrm{C}$ is buried in the sediment of Scotland's fjords.

- Fjord sediments are potentially the most effective store of C globally.

\section{Introduction}

Globally there is growing recognition that the burial (Smith et al., 2015) and storage (Smeaton et al., 2016) of carbon (C) in coastal marine sediments is an important factor in the global carbon cycle (Bauer et al., 2013) that provides an essential climate-regulating service (Smith et al., 2015). Coastal sediments have been shown to be globally significant repositories for C, with an estimated $126.2 \mathrm{Mt}$ of $\mathrm{C}$ being buried annually (Duarte et al., 2005). Of the different coastal depositional environments, fjords have been shown to be "hotspots" for C burial, with approximately $11 \%$ of the annual global marine carbon sequestration occurring within fjordic environments (Smith et al., 2015). Although it is clear that these areas are important for the burial and long-term storage of $\mathrm{C}$, the actual quantity of $\mathrm{C}$ held within coastal sediment remains largely unaccounted for. This knowledge 
Table 1. Key physical characteristics (Edwards and Sharples, 1986) of each of the five fjords selected to produce detailed estimates of sedimentary C stocks.

\begin{tabular}{lrrrrrr}
\hline Fjord & $\begin{array}{r}\text { Length } \\
(\mathrm{km})\end{array}$ & $\begin{array}{r}\text { Area } \\
\left(\mathrm{km}^{2}\right)\end{array}$ & $\begin{array}{r}\text { Mean depth } \\
(\mathrm{m})\end{array}$ & $\begin{array}{r}\text { Max depth } \\
(\mathrm{m})\end{array}$ & $\begin{array}{r}\text { Catchment size } \\
\left(\mathrm{km}^{2}\right)\end{array}$ & $\begin{array}{r}\text { Fresh to tidal } \\
\text { ratio }\end{array}$ \\
\hline Loch Etive & 29.5 & 27.7 & 33.9 & 139 & 1350 & 120.4 \\
Loch Creran & 12.8 & 13.3 & 13.4 & 49 & 164 & 12.5 \\
Loch Broom & 14.7 & 16.8 & 27.3 & 87 & 353 & 14 \\
Little Loch Broom & 12.7 & 20.4 & 41.7 & 110 & 167 & 5.5 \\
Loch Sunart & 30.7 & 47.3 & 38.9 & 124 & 299 & 5.3 \\
\hline
\end{tabular}

deficit hinders our ability to fully evaluate, manage and protect these coastal $\mathrm{C}$ stores and the climate-regulating service that they provide.

The quantification of $\mathrm{C}$ in fjordic sediments was identified as a priority by Syvitski et al. (1987), but little progress has been made towards this goal until recently. Our work presented here utilises and extends the joint geochemistry and geophysical methodology developed by Smeaton et al. (2016) by applying it to a number of mid-latitude fjords. Estimated sedimentary $\mathrm{C}$ stocks for individual fjords will be utilised to create the first national estimate of sedimentary $\mathrm{C}$ stocks in the coastal ocean and thus quantify an overlooked aspect of Scotland's natural capital.

\section{Scotland's fjords}

The coastal landscape of the west coast and islands of Scotland is dominated by fjordic geomorphology (Cage and Austin, 2010; Nørgaard-Pedersen et al., 2006). Catchments with a total area of $21742 \mathrm{~km}^{2}$ drain to the sea through fjords, thus transporting sediment from the $\mathrm{C}$-rich soils into the marine system (Bradley et al., 2005). There are 111 large fjords (over $2 \mathrm{~km}$ long, with fjord length twice fjord width; Fig. 1) in Scotland (Edwards and Sharples, 1986), supplemented by a further 115 smaller systems. The 111 large fjords are the primary focus of this study because their size and heavily glaciated geomorphology (Howe et al., 2002) suggest they are likely to store significant quantities of postglacial sediment. Additionally, geomorphological and oceanographic datasets are readily available for these fjords.

Building on the work of Smeaton et al. (2016), which centred on Loch Sunart $(56.705556,-5.737534)$, we focus on a further four fjords to develop site-specific sedimentary C stock estimations, which then allow us to make more precise estimates for the same range of fjordic system types in Scotland. The chosen sites are Loch Etive (56.459224, -5.311151), Loch Creran (56.536970, -5.324578), Loch Broom (57.873974, -5.117443) and Little Loch Broom (57.872144, -5.316385; Fig. 1). These fjords differ significantly in their physical characteristics (Table 1) and bottom water oxygen conditions. Hypoxic bottom water conditions are recognised as an important factor in $\mathrm{C}$ burial and preser- vation within depositional coastal environments (Middelburg and Levin, 2009; Woulds et al., 2007). However, of these 111 fjords, only Loch Etive's upper basin is known to be permanently hypoxic (Friedrich et al., 2014). Modelling of deep water renewal in the 111 fjords suggests that between 5 and 28 fjords, including Loch Broom and Little Loch Broom, could experience intermittent periods of hypoxia, while this is less likely in Loch Sunart and Loch Creran (Gillibrand et al., 2005, 2006).

\section{Towards a national fjordic sedimentary carbon inventory}

\subsection{Sample and data collection}

This study applies the methodology of Smeaton et al. (2016) in which sediment cores and seismic geophysical data were collected for four additional fjords. Figure 1 shows the location of each of the long $(>1 \mathrm{~m})$ sediment cores extracted from the four fjords chosen to produce detailed sedimentary C stock estimates. With the exception of Loch Creran, for which the required data were extracted from the available literature (Cronin and Tyler, 1980; Loh et al., 2008), each core was subsampled at $10 \mathrm{~cm}$ intervals for analysis. In total, 285 subsamples were collected from the sediment cores from Loch Etive $(n=133)$, Loch Broom $(n=78)$ and Little Loch Broom $(n=74)$. The data produced by Smeaton et al. (2016) for the glacially derived sediment in Loch Sunart were used as a surrogate for all glacial sediments in this study since MD04-2833 remains the only mid-latitude fjord core with chronologically constrained glacial sediment (Baltzer et al., 2010). Detailed seabed seismic geophysical data for Loch Etive (Howe et al., 2002), Loch Creran (Mokeddem et al., 2015), Loch Broom (Stoker and Bradwell, 2009) and Little Loch Broom (Stoker et al., 2010) were compiled.

In addition, sediment surface samples $(n=61)$ and partial seismic surveys $(n=5)$ have been collected from a number of additional fjords (Fig. 1). These, in conjunction with data from the literature (Russell et al., 2010; Webster et al., 2004), provide a greater understanding of $\mathrm{C}$ abundance in these sediments and assist in constraining upscaling efforts. The full dataset is presented in the Supplement. 

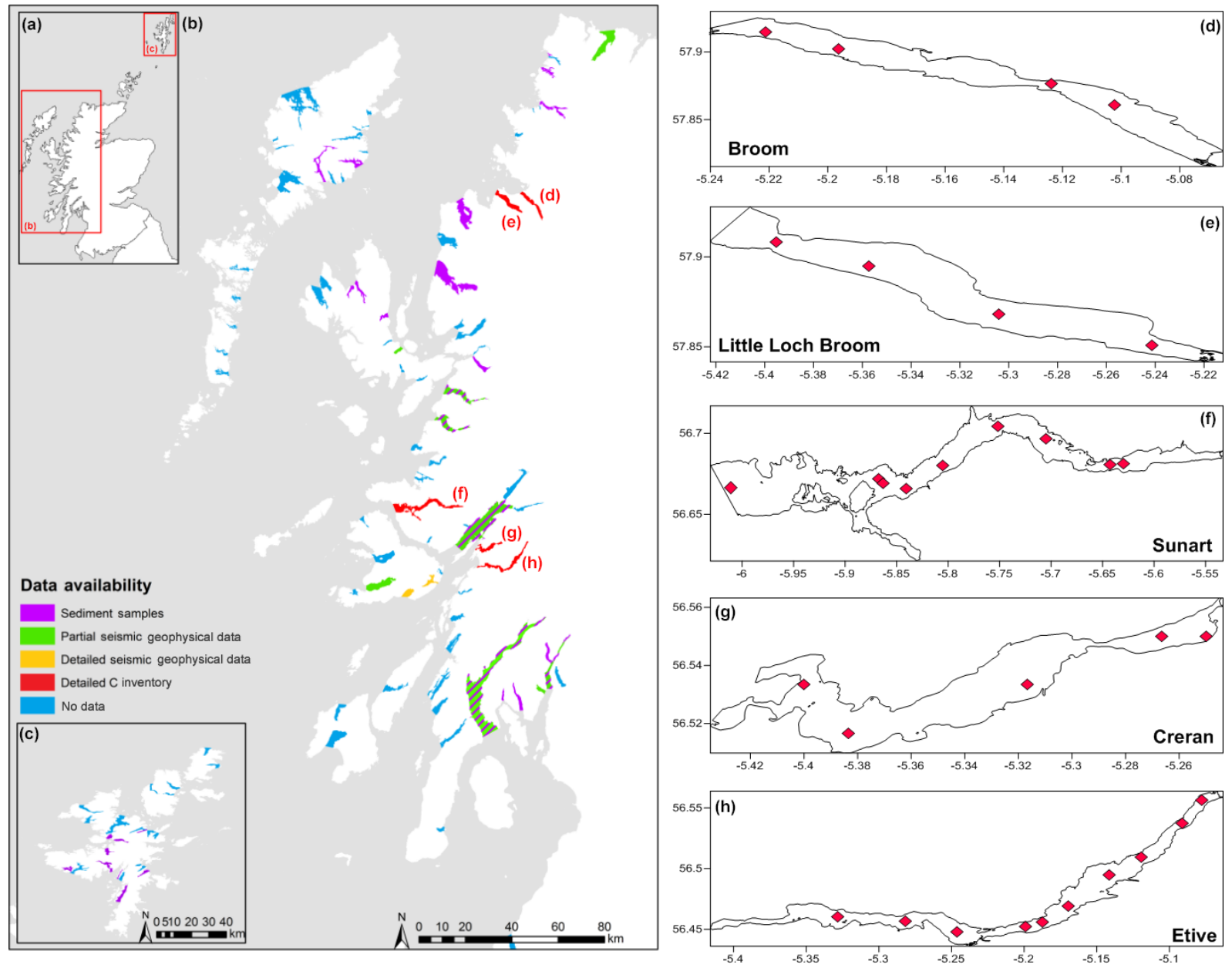

Figure 1. Map illustrating the location of Scotland's 111 fjords and the available data. Additionally, detailed maps present the sampling locations within (d) Loch Broom, (e) Little Loch Broom, (f) Loch Sunart (Smeaton et al., 2016), (g) Loch Creran (Loh et al., 2008) and (h) Loch Etive.

\subsection{Analytical methods}

Each of the subsamples was split for physical and geochemical analyses. The dry bulk density (DBD) of the sediment was calculated following Dadey et al. (1992). All samples were freeze-dried, milled and analysed for total carbon (TC) and nitrogen $(\mathrm{N})$ using a Costech elemental analyser (Verardo et al., 1990). Subsamples of the same samples then underwent carbonate removal through acid fumigation (Harris et al., 2001) and elemental analysis to quantify the organic carbon (OC) content. The inorganic carbon (IC) content of the sediment was calculated by deducting the OC from the TC. Analytical precision was estimated from repeat analysis of standard reference material B2178 (Medium Organic Content Standard; Elemental Microanalysis, UK) with $\mathrm{C}=0.08 \%$ and $\mathrm{N}=0.02 \%(n=40)$.

\subsection{Fjord-specific sedimentary carbon inventories}

Following the methodology of Smeaton et al. (2016), the geochemical and seismic geophysical data were combined to make first-order estimates of the $\mathrm{C}$ held in the postglacial and glacial sediments of Loch Etive, Loch Creran, Loch Broom and Little Loch Broom. We then calculated how effectively the fjord stores $\mathrm{C}\left(\mathrm{C}_{\mathrm{eff}}\right)$ as a depth-integrated average value per $\mathrm{km}^{2}$ for both the postglacial and glacial-derived sediments. Unlike Loch Sunart, where the sediment stratigraphy has robust chronological constraints (Cage and Austin, 2010; Smeaton et al., 2016), the four other fjords largely lack chronological evidence, with the exception of two cores from Loch Etive (Howe et al., 2002; Nørgaard-Pedersen et al., 2006). The lack of ${ }^{14} \mathrm{C}$ dating means we rely solely on the interpretation of the seismic geophysics to differentiate between the postglacial and glacial sediments. To ensure the consistency of this approach, previous seismic interpretations of Scottish fjordic sediments (Baltzer et al., 2010; Dix 
and Duck, 2000; Howe et al., 2002; Stoker and Bradwell, 2009; Stoker et al., 2010) were studied and a catalogue of different seismic facies was compiled for use as a reference guide (Supplement). Finally, we applied the framework set out in Smeaton et al. (2016) to reduce uncertainty in the interpretation of the seismic geophysics by testing seismic units against available dated sediment cores.

\subsection{Upscaling to a national sedimentary carbon inventory}

Upscaling from individual to national coastal $\mathrm{C}$ estimates was the key objective of this work. Two approaches were developed to upscale the five detailed sedimentary $\mathrm{C}$ inventories to a national-scale stock assessment of $\mathrm{C}$ in the sediment of the 111 major Scottish fjords. Both approaches utilise the physical characteristics of the fjords to quantify the $\mathrm{OC}$ and IC held within the sediment. From these data we can also estimate the long-term average quantity of $\mathrm{C}$ buried each year. Currently, the best estimate of when the west coast of Scotland was free of ice from the last glacial period is approximately $13.5 \mathrm{ka}$ (Lambeck, 1993), though it could be argued that $15 \mathrm{ka}$ or $11.5 \mathrm{ka}$ would be more appropriate. Modelling of the retreat of the last ice sheet (Clark et al., 2012) suggests that a significant number of the fjords would have been ice free around $15 \mathrm{ka}$ (Supplement) and have the ability to start accumulating C. Alternatively, $11.5 \mathrm{ka}$ (Golledge, 2010) could be used as this date signifies the point at which the fjords became permanently ice free after the loss of ice associated with the Younger Dryas period. By dividing the total $\mathrm{C}$ held within the postglacial sediment in all the fjords by this range of dates we can calculate the long-term average quantity of $\mathrm{C}$ buried per year since the start of the postglacial period. Although the methodology is relatively crude and probably underestimates the quantity of $\mathrm{C}$ being buried each year, it does give a valuable first-order insight into the long-term carbon sequestration service that fjords prove.

\subsubsection{Fjord classification approach}

The first stage of upscaling involves grouping the 111 fjords using the physical characteristics identified in Table 1, along with rainfall, tidal range and run-off data. Grouping was achieved by applying a k-means cluster analysis $\left(1 \times 10^{5}\right.$ iterations) to all 111 fjords (Edwards and Sharples, 1986). This resulted in the delineation of four groups (Fig. 2). Group 1 contains mainly mainland fjords which are the most deeply glaciated and have highly restrictive submarine geomorphology (Gillibrand et al., 2005); Loch Sunart and Loch Creran fall into this category. Group 2 contains fjords from the mainland and the Inner Hebrides which tend to be less deeply glaciated and more open systems; Loch Broom and Little Loch Broom are part of this group. Group 3 includes the fjords on Shetland and the Outer Hebrides; these fjords are shallower and their catchments tend to be smaller and notice- ably less glaciated. Group 4 consists of Loch Etive and Loch Linnhe; these fjords are outliers from the other groups, both have extremely large catchments in comparison to the others and were major glacial conduits for ice draining from the central Scottish ice field at the last glacial period. This analysis suggests that the level to which the fjords are glaciated is a defining factor in how they are classified. When mapped, the ice thickness at the last glacial maximum (Lambeck et al., 1993) largely correlates with the groupings produced by the k-means analysis (Supplement) with Group 1 under the maximum amount of ice, which reduces in thickness for each subsequent group. Our case study fjords are thus representative of three of the fjordic groups that can be recognised on a national scale. Group-specific postglacial and glacial $\mathrm{OC}_{\text {eff }}$ and $\mathrm{IC}_{\text {eff }}$ were calculated using the data from the detailed sedimentary $\mathrm{C}$ inventories available from our five sites. The group-specific $\mathrm{OC}_{\text {eff }}$ and $\mathrm{IC}_{\text {eff }}$ were applied to each fjord within a group, giving the total OC and IC stock for each fjord. Group 3 does not contain any of the five fjords for which there are detailed $\mathrm{C}$ stock estimations and Group 2 has therefore been chosen as a surrogate since the k-means analysis indicates that Groups 2 and 3 have the greatest similarities.

\subsubsection{Physical attribute approach}

The physical characteristics of fjords (Table 1) have primarily governed the input of $\mathrm{C}$ into the fjord since the end of the last glaciation (McIntyre and Howe, 2010) when the majority of fjords became ice free. We might therefore expect a relationship between the physical features of a given fjord and its accompanying catchment and the $\mathrm{C}$ stored in its sediments. We use detailed sedimentary $\mathrm{C}$ stock estimations in conjunction with the physical characteristics (Edwards and Sharples, 1986) to determine which physical feature best correlates with the quantity of OC and IC held in the sediment. A statistical scoping exercise was therefore undertaken to determine which physical characteristics are best suited to the upscaling process (Supplement). The results indicate that there are strong linear relationships between $\mathrm{OC}_{\text {eff }}$ and tidal range $\left(p=0.012, R^{2}=0.909\right)$, precipitation $\left(p=0.003, R^{2}=0.961\right)$, catchment area $(p=0.023$, $\left.R^{2}=0.860\right)$ and run-off $\left(p=0.019, R^{2}=0.877\right)$. The correlation between these physical features and OC content fits well with our understanding of fjord processes, since tidal range is a proxy for the geomorphological restrictiveness of the fjord, while catchment size, precipitation and run-off govern the input of terrestrially derived OC (Cui et al., 2016) into the fjord. The relationship between the IC stored in the sediment and a fjord's physical characteristics is less well defined, with strong correlations identified between IC and the area of the fjord ( $\left.p=0.009, R^{2}=0.925\right)$ and the length of the fjord ( $\left.p=0.016, R^{2}=0.892\right)$. Again, this fits with what we would expect: the larger and/or longer the fjord, the greater the opportunity for in situ IC production (Ata- 


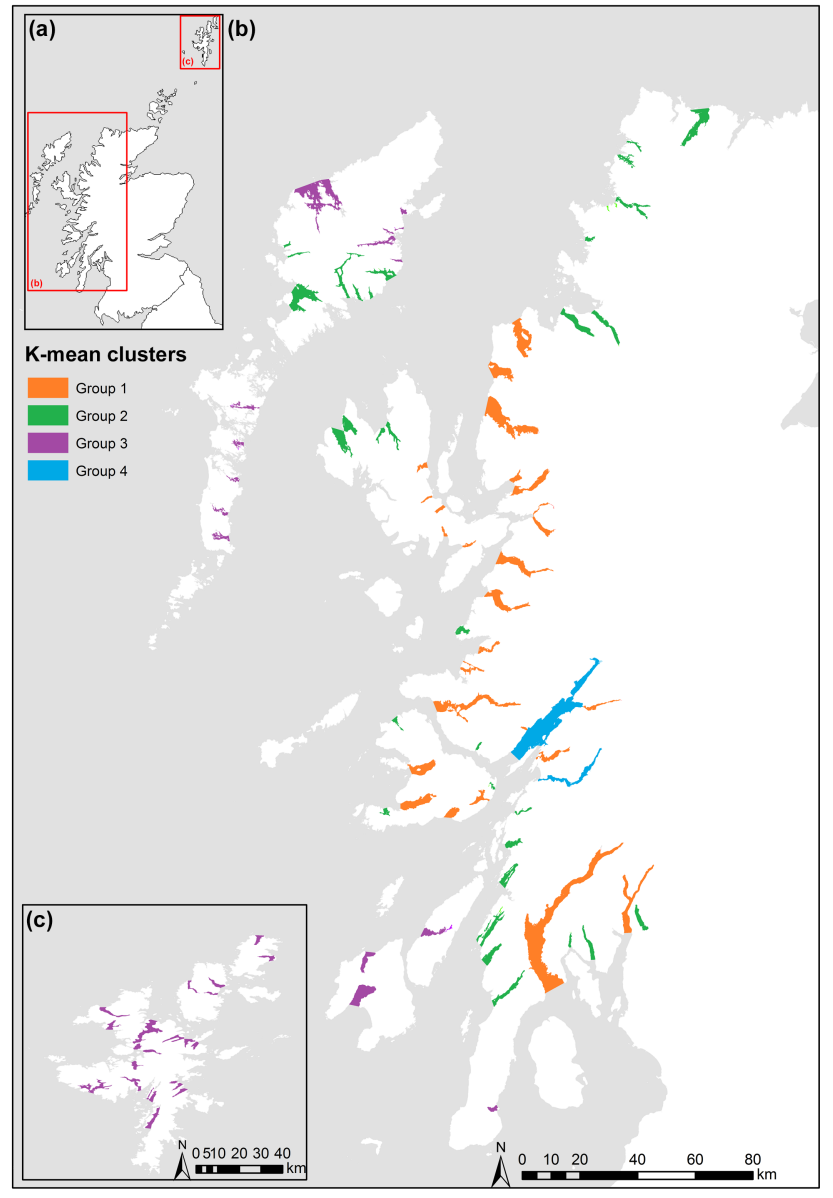

Figure 2. Output from the k-means analysis showing the spatial distribution of the four different groups of fjords.

manchuk et al., 2015) and remineralisation of OC (Bianchi et al., 2016). Each of these relationships was used to calculate the OC and IC stored in the postglacial sediment of each of the 111 fjords. The input of glacially derived OC during the retreat of the ice sheet at approximately $13.5-17 \mathrm{ka}$ (Clark et al., 2012) is controlled by more sporadic mechanisms (Brazier et al., 1988) governed by complex advanceretreat ice margin dynamics during the deglaciation. This approach is therefore not suitable for estimating the $\mathrm{C}$ stored in the glacial sediment of the fjords.

\subsubsection{Constraining estimates and uncertainty}

To determine the accuracy of both upscaling methodologies, we compared the total quantity of sedimentary OC and IC calculated for Loch Sunart, Loch Etive, Loch Creran, Loch Broom and Little Loch Broom by both upscaling approaches alongside detailed estimates of $\mathrm{C}$ held within the sediment of each of the five fjords. Although there are insufficient data to create additional detailed sedimentary $\mathrm{C}$ stock estimates on a national

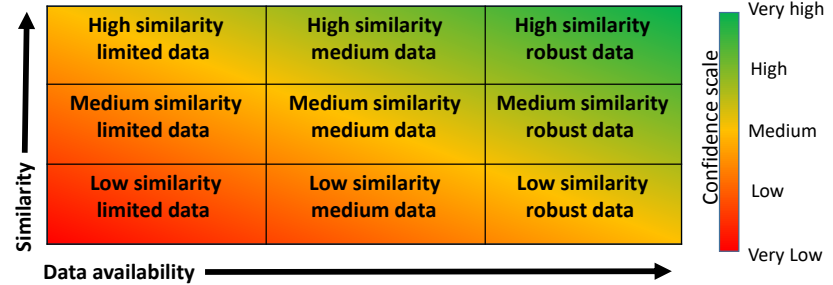

Figure 3. Matrix depicting the relationship between data availability, similarity to modelled fjords and confidence level. Adapted from IPCC 5th Assessment Report (Mastrandrea et al., 2010).

scale, there are enough data from some fjords to make broad estimations (Supplement data). Seismic geophysical data from Loch Hourn (57.125683, -5.589578), Loch Eriboll (58.497543, -4.685106), Loch Fyne (55.882882, -5.381012), Nevis (57.007023, -5.693133) and Lower Loch Linnhe $(56.591510,-5.456910)$ allow us to estimate the minimum and maximum depth of postglacial sediment, while surface sample data from each loch enable us to estimate the $\mathrm{C}$ content of the sediment. Using these data we can calculate basic estimates of postglacial OC and IC held within the sediment of these fjords as an additional check on the accuracy of the upscaling methodology.

Two metrics of uncertainty were employed: arithmetic and a confidence-driven approach. The arithmetic method follows the approach of Smeaton et al. (2016), whereby any known arithmetic uncertainty is propagated through all the calculations. However, as recognised by Smeaton et al. (2016), there are "known unknowns" which we cannot reliably quantify. Therefore we have further employed a confidence-driven approach to assess the final $\mathrm{C}$ stock estimations for each fjord. Using a modified confidence matrix (Fig. 3) following the protocols adopted in the IPPC 5th Assessment (Mastrandrea et al., 2010), we have semiquantitatively assigned a level of confidence to the $\mathrm{C}$ estimates from each fjord. The matrix uses the results from the k-means analysis and the availability of secondary data (Supplement) to assign a confidence level. For example, as described above (Sect. 3.4.1) a fjord in the Outer Hebrides would fall into Group 3. As discussed, this group is without a detailed sedimentary carbon inventory and no other data are available to test the calculated $\mathrm{C}$ inventory. In this case, the $\mathrm{C}$ stock estimation for that fjord would be assigned a very low confidence level. In contrast, if the fjord fell into to Group 1, in which there are similar fjords with detailed $\mathrm{C}$ stock estimations and further $\mathrm{C}$ and partial geophysical data were available to test the calculated $\mathrm{C}$ inventory, then a high confidence level would be assigned. The five fjords with detailed sedimentary $\mathrm{C}$ inventories are the only sites which have been assigned a confidence level of very high. 

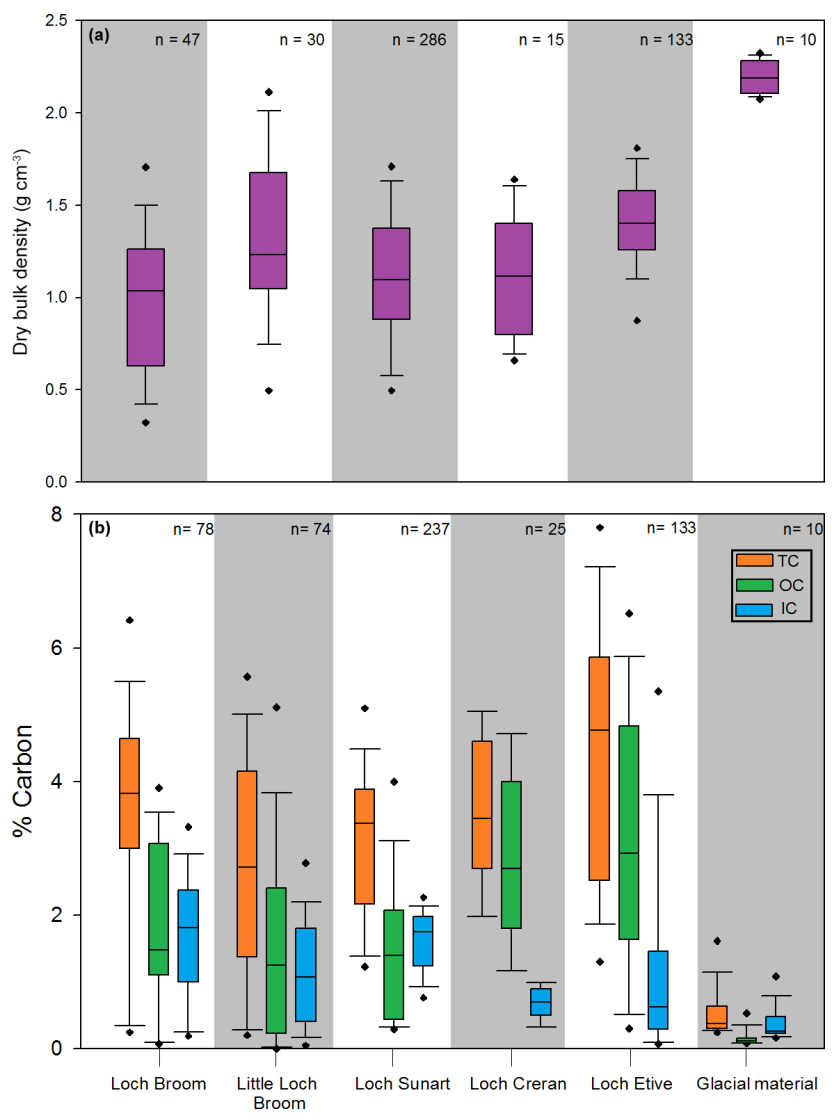

Figure 4. Box plots illustrating the (a) dry bulk density and (b) carbon content $(\%)$ compiled from the sediment cores extracted from the five fjords central to this research. Data for the glacially derived sediments collected from Loch Sunart (MD04-2833) are also presented.

\section{Interpretation and discussion}

\subsection{Fjord-specific sedimentary carbon inventories}

Sedimentary analyses showed a broad similarity in dry bulk density values from the postglacial sediment of the five fjords, while the variability between the fjords is more clearly illustrated by the carbon concentrations (Fig. 4). Loch Broom, Loch Sunart and Little Loch Broom are characterised by similar quantities of OC and IC. Although the TC content of the sediment in Loch Creran is comparable to the other fjords, the relative contribution of OC is higher, with a correspondingly lower quantity of IC in the sediment. Of the five lochs surveyed, the $\mathrm{C}$ content of Loch Etive's sediment is significantly different from the other sites. It has the highest TC content due to the high quantities of OC found in the sediment. This is a possible consequence of hypoxic conditions in the inner basin, as discussed below. As expected, the highest dry bulk density values and lowest quantity of OC and IC occur in the glacial sediments at all sites.
The total $\mathrm{C}$ held within each of the five fjords (Table 2) was calculated by combining the bulk density data, $\% \mathrm{C}$ and sediment volume models (Supplement). Loch Sunart $(26.9 \pm 0.5 \mathrm{MtC})$ contains the largest sedimentary $\mathrm{C}$ store of the five fjords, closely followed by Loch Etive $(21.1 \pm 0.3 \mathrm{MtC})$. In comparison, Loch Creran, Loch Broom and Little Loch Broom hold significantly less C. As indicated above, the postglacial sediments of Loch Etive hold the greatest quantity of OC $(11.5 \pm 0.4 \mathrm{Mt})$ with $7.76 \mathrm{Mt}$ of that OC held in the upper hypoxic basin, resulting in Loch Etive being the most effective store of OC $\left(0.455 \mathrm{Mt} \mathrm{OC} \mathrm{km}^{-2}\right)$. These results suggest that low oxygen conditions inhibit the reworking and remineralisation of organics and the production of carbonate fauna (Woulds et al., 2016). Loch Sunart has large sills (Smeaton et al., 2016) and is one of the largest fjords in Scotland; these features favour the capture of terrestrial OC (Smeaton and Austin, 2017) and the storage of large quantities of postglacial OC $(9.4 \pm 0.2 \mathrm{Mt})$ and IC $(10.1 \pm 0.2 \mathrm{Mt})$. The quantities of $\mathrm{C}$ stored in the sediment of the smaller fjords are strongly linked to how restrictive the geomorphology of the fjord is. For example, the smallest quantity of IC is held within Loch Creran. This is in part due to the shallow and narrow central sill, which results in a terrestrially dominated system with high sedimentation rates (Loh et al., 2008) that increase the OC storage effectiveness $\left(0.195 \mathrm{Mt} \mathrm{OC} \mathrm{km}^{-2}\right)$ but reduce the IC storage effectiveness $\left(0.068 \mathrm{Mt} \mathrm{IC} \mathrm{km}^{-2}\right)$. Increased humic acid input from terrestrial sources (Bauer and Bianchi, 2011) results in lower $\mathrm{pH}$, which in turn reduces the suitability of the fjord for calcifying organisms (Khanna et al., 2013). In contrast, the relatively unrestricted geomorphology of Loch Broom results in the fjord being governed by marine processes. The greater marine influence results in this ecosystem being capable of supporting a greater range and abundance of calcifying organisms (e.g. foraminifera), which in turn make the sediments a highly effective store of IC $0.232 \mathrm{Mt} \mathrm{IC} \mathrm{km}^{-2}$. In contrast, these open systems are comparatively poor at capturing $\mathrm{OC}$ as illustrated by Little loch Broom (1.6 Mt OC). The glacial material contains less $\mathrm{C}$ than the postglacial sediments. The effective storage of $\mathrm{C}$ in the glacially derived sediments of the five fjords is very similar, with the $\mathrm{OC}_{\mathrm{eff}}$ ranging between 0.030 and $0.093 \mathrm{Mt} \mathrm{OC} \mathrm{km}^{-2}$ and an $\mathrm{IC}_{\mathrm{eff}}$ varying between 0.068 and $0.104 \mathrm{Mt} \mathrm{IC} \mathrm{km}^{-2}$ (Table 2). The similarity of these results may be because the mechanisms governing the deposition of glacial sediment during the retreat of the British Ice Sheet (Brazier et al., 1988) were similar across the geographic range of the fjords, but it may also be a product of limited data availability for the glacial sediment.

\subsection{A national fjordic sedimentary $C$ inventory}

The results of the upscaling process (Table 3 ) suggest that an overall estimated $640.7 \pm 46 \mathrm{Mt}$ of $\mathrm{C}$ are stored in the fjordic sediments of Scotland, comprising $295.6 \pm 52 \mathrm{Mt}$ of OC and 
Table 2. Detailed sedimentary C stocks presented as total carbon (TC), organic carbon (OC) and inorganic carbon (IC) held within the postglacial (PG) and glacial (G) sediment of the fjords. Additionally, we list the $\mathrm{C}_{\text {eff }}$ for each fjord as a measure of how effectively the sediment stores $\mathrm{C}$.

\begin{tabular}{lrrrrrr}
\hline Fjord & TC $(\mathrm{Mt})$ & $\mathrm{OC}(\mathrm{Mt})$ & $\mathrm{IC}(\mathrm{Mt})$ & $\mathrm{C}_{\text {eff }}\left(\mathrm{MtC} \mathrm{km}^{-2}\right)$ & $\mathrm{OC}_{\text {eff }}\left(\mathrm{Mt} \mathrm{OC} \mathrm{km}^{-2}\right)$ & $\mathrm{IC}_{\text {eff }}\left(\mathrm{Mt} \mathrm{IC} \mathrm{km}^{-2}\right)$ \\
\hline Loch Etive & $21.1 \pm 0.3$ & $12.6 \pm 0.3$ & $8.6 \pm 0.3$ & 0.766 & 0.455 & 0.311 \\
PG & $17.7 \pm 0.4$ & $11.5 \pm 0.4$ & $6.2 \pm 0.3$ & 0.639 & 0.415 & 0.224 \\
G & $3.5 \pm 0.2$ & $1.1 \pm 0.1$ & $2.4 \pm 0.2$ & 0.127 & 0.040 & 0.087 \\
\hline Loch Creran & $4.8 \pm 0.7$ & $3 \pm 0.5$ & $1.8 \pm 0.9$ & 0.361 & 0.225 & 0.136 \\
PG & $3.5 \pm 0.6$ & $2.6 \pm 0.7$ & $0.9 \pm 0.4$ & 0.268 & 0.195 & 0.068 \\
G & $1.3 \pm 0.9$ & $0.4 \pm 0.1$ & $0.9 \pm 1.2$ & 0.098 & 0.030 & 0.068 \\
\hline Loch Broom & $6.8 \pm 0.4$ & $2.9 \pm 0.4$ & $3.9 \pm 0.4$ & 0.405 & 0.173 & 0.232 \\
PG & $5.1 \pm 0.5$ & $2.4 \pm 0.5$ & $2.7 \pm 0.4$ & 0.304 & 0.143 & 0.161 \\
G & $1.7 \pm 0.3$ & $0.5 \pm 0.2$ & $1.2 \pm 0.3$ & 0.101 & 0.030 & 0.071 \\
\hline Little Loch Broom & $7 \pm 0.5$ & $3.5 \pm 0.5$ & $3.5 \pm 0.6$ & 0.344 & 0.171 & 0.173 \\
PG & $3 \pm 0.7$ & $1.6 \pm 0.6$ & $1.4 \pm 0.8$ & 0.148 & 0.078 & 0.070 \\
G & $4 \pm 0.3$ & $1.9 \pm 0.2$ & $2.1 \pm 0.4$ & 0.196 & 0.093 & 0.103 \\
\hline Loch Sunart & $26.9 \pm 0.5$ & $11.5 \pm 0.2$ & $15.0 \pm 0.4$ & 0.560 & 0.243 & 0.317 \\
PG & $19.9 \pm 0.3$ & $9.4 \pm 0.2$ & $10.1 \pm 0.2$ & 0.412 & 0.199 & 0.213 \\
G & $7.0 \pm 0.8$ & $2.1 \pm 0.3$ & $4.9 \pm 0.6$ & 0.148 & 0.044 & 0.104 \\
\hline
\end{tabular}

Table 3. Total C stored in the sediment of Scotland's 111 fjords further broken down into the quantities of OC and IC stored in the postglacial and glacial sediments.

\begin{tabular}{lrrr}
\hline & TC $(\mathrm{Mt})$ & OC $(\mathrm{Mt})$ & IC $(\mathrm{Mt})$ \\
\hline Postglacial & $467.1 \pm 65$ & $252.4 \pm 62$ & $214.7 \pm 85$ \\
Glacial & $173.6 \pm 18$ & $43.2 \pm 12$ & $130.6 \pm 22$ \\
\hline Total & $640.7 \pm 46$ & $295.6 \pm 52$ & $345.1 \pm 39$
\end{tabular}

$345.1 \pm 39 \mathrm{Mt}$ of IC. The postglacial sediments are the main repository for much of this $\mathrm{C}$, with almost equal amounts of OC and IC indicated by an OC: IC ratio of $1.17: 1$. In contrast, the glacial sediments are dominated by IC, with an OC: IC ratio of $0.33: 1$. This is most likely due to the glacial source material originating from scoured bedrock and the absence of organic-rich soils and vegetation (Edwards and Whittington, 2010). The storage of $\mathrm{C}$ is unevenly distributed between the 111 fjords; a small number of systems disproportionately contribute to the national sedimentary $\mathrm{C}$ total (Fig. 5). The sediment of 14 large fjords holds $65 \%$ of the total C in Scotland's fjords (Table 4). Estimated C stocks for individual fjords can be found in the Supplement.

In addition to quantifying the total $\mathrm{C}$ stored in these fjords, we also calculated the accuracy of the upscaling process (Supplement) and assigned a confidence level to each of the sedimentary C estimates using the confidence matrix (Fig. 3). The availability of data for the postglacial sediment means that we have medium to very high confidence in our estimates of the quantity of OC and IC stored in 74 of the 111

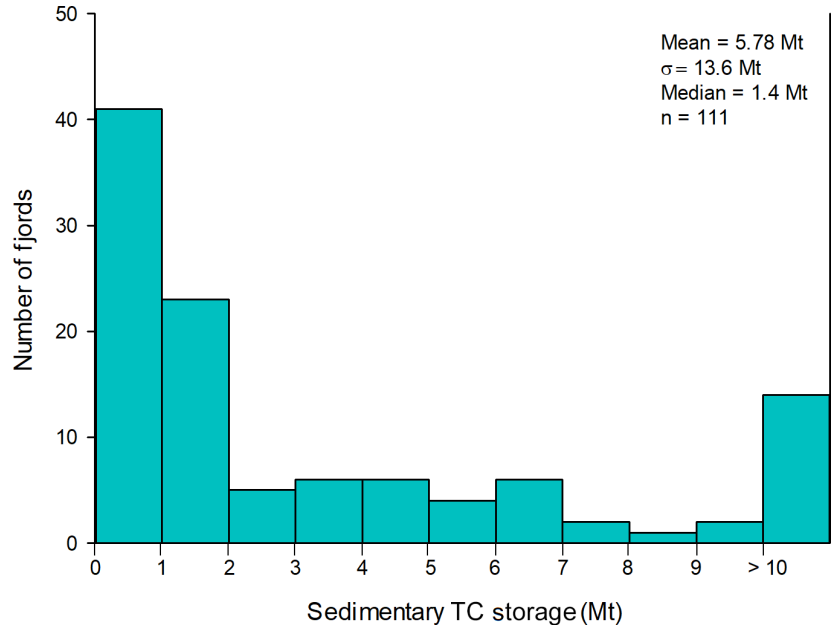

Figure 5. Frequency distribution of sedimentary TC stock estimates for Scotland's 111 fjords.

fjords. The remaining 37 fjords have been assigned a confidence level of low, with most originating from Group 3 of the k-means analysis for which we recognise a shortage of the data needed to constrain $\mathrm{C}$ stock estimates. The lack of data for glacially derived sediment results in all except the five case study lochs being assigned a confidence level of very low to medium. Using these checks we believe that our first-order estimate of the $\mathrm{C}$ stored in the sediment of Scotland's fjords and the associated uncertainties are realistic and robust. The confidence level assigned to each fjordic $\mathrm{C}$ estimate stock can be found in the Supplement. 
Table 4. Details of the 14 fjords that disproportionately contribute to Scotland's fjordic sedimentary C stock.

\begin{tabular}{lrr}
\hline Fjord & TC (Mt) & \multicolumn{2}{c}{$\begin{array}{r}\text { of Scotland's total of } \\
\text { fjordic sedimentary C stock }\end{array}$} \\
\hline Loch Fyne & 99.70 & 15.56 \\
Loch Linnhe (lower) & 92.28 & 14.40 \\
Loch Torridon & 30.82 & 4.81 \\
Loch Linnhe (upper) and Eil & 27.82 & 4.34 \\
Loch Sunart & 26.50 & 4.14 \\
Loch Ewe & 21.82 & 3.41 \\
Loch Etive & 21.11 & 3.29 \\
Long Clyde & 16.60 & 2.59 \\
Loch Hourn & 15.41 & 2.41 \\
Loch Ryan & 14.35 & 2.24 \\
Loch na Keal & 14.29 & 2.23 \\
Loch Nevis & 13.08 & 2.04 \\
Loch Scridian & 12.01 & 1.87 \\
Loch Carron & 10.52 & 1.64 \\
\hline
\end{tabular}

\subsubsection{National estimates of $\mathrm{C}$ burial}

Annually, an estimated $31139-40615 \mathrm{t}$ of $\mathrm{C}$ is buried in the sediment of the 111 fjords, with OC contributing 16828 $21949 \mathrm{tyr}^{-1}$ and IC supplying $14311-18666 \mathrm{tyr}^{-1}$. This annual burial of $\mathrm{C}$ has been suggested to provide a climateregulating service through $\mathrm{C}$ sequestration (Smith et al., 2015), yet efforts to fully quantify this mechanism have remained elusive. The results from this study indicate that fjords have been capturing OC since the retreat of the last ice sheet, some of which would have otherwise been lost to the open ocean where it would be more readily remineralised (Middelburg et al., 1993; Bianchi, 2011). Although the results do little to resolve the mechanisms that govern this climate-regulating service, they clearly show that fjords have been providing this service since the retreat of the last ice sheet and throughout the Holocene. This suggests that these systems have the capacity to adapt to future environmental change. Intriguingly, there is also the possibility that this process may have aided the capture of terrestrial $\mathrm{C}$ during the late Holocene and recent past (Smeaton and Austin, 2017).

\subsubsection{Global outlook}

Given similarities between the mid-latitude fjords and the coastal environments of New Zealand, Chile, Norway and Canada (Syvitski and Shaw, 1995), it is reasonable to suggest that our findings are relevant throughout these systems. The sediments within fjordic environments around the world potentially hold significant quantities of both OC and IC which have been overlooked in national and global carbon budgets. The joint geophysical and geochemical methodology used to quantify sedimentary $\mathrm{C}$ stocks coupled to the upscaling approach taken in this study is capable of providing nations around the world with the ability to quantify their coastal sedimentary C stocks and reassess their nation's natural capital.

\subsection{Comparison to other mid-latitude carbon stocks: significance and vulnerability}

The $640.7 \pm 46 \mathrm{Mt}$ of carbon held within the sediment of the fjords is one of the largest stores in Scotland (Fig. 6). The fjordic sedimentary store is the largest of Scotland's coastal carbon stores (Burrows et al., 2014), exceeding both maerl and biogenic reefs, which have been shown to be highly effective stores of both OC and IC (van Der Heijden and Kamenos, 2015). In addition, fjord sediments hold a greater quantity of $\mathrm{C}$ than all the living vegetation in Scotland (Forestry Commission, 2015; Henrys et al., 2016; Vanguelova et al., 2013). While Scotland's soils (Aitkenhead and Coull, 2016), particularly the peatlands (Chapman et al., 2009), contain a greater quantity of OC than the fjords, it must be remembered that the fjord sediments also hold IC and the areal extent of these stores differs greatly. When normalised by area (Fig. 6), fjordic sediments emerge as a far more effective store of OC and IC than other Scottish C stores on land or at sea.

Globally, there are no direct comparisons as this is the first national C inventory of marine sediments. Recent work in Denmark suggested that the Thurøbund seagrass meadow was one of the most effective stores of $\mathrm{C}$ in the world, storing $0.027 \mathrm{Mt} \mathrm{C} \mathrm{km}^{-2}$ (Röhr et al., 2016). On an aerial basis, however, these seagrass meadows are significantly less effective than fjord sediments, which hold $0.219 \mathrm{Mt} \mathrm{OC} \mathrm{km}^{-2}$ and $0.256 \mathrm{Mt} \mathrm{IC} \mathrm{km}^{-2}$. This disparity emerges because Röhr et al. (2016) only consider the top $0.25 \mathrm{~m}$ of seagrass sediment, while our study encompassed the full depth of sediment. In Loch Sunart, for example, sediment depths of $70 \mathrm{~m}$ have been recorded (Baltzer et al., 2010). When compared like for like 


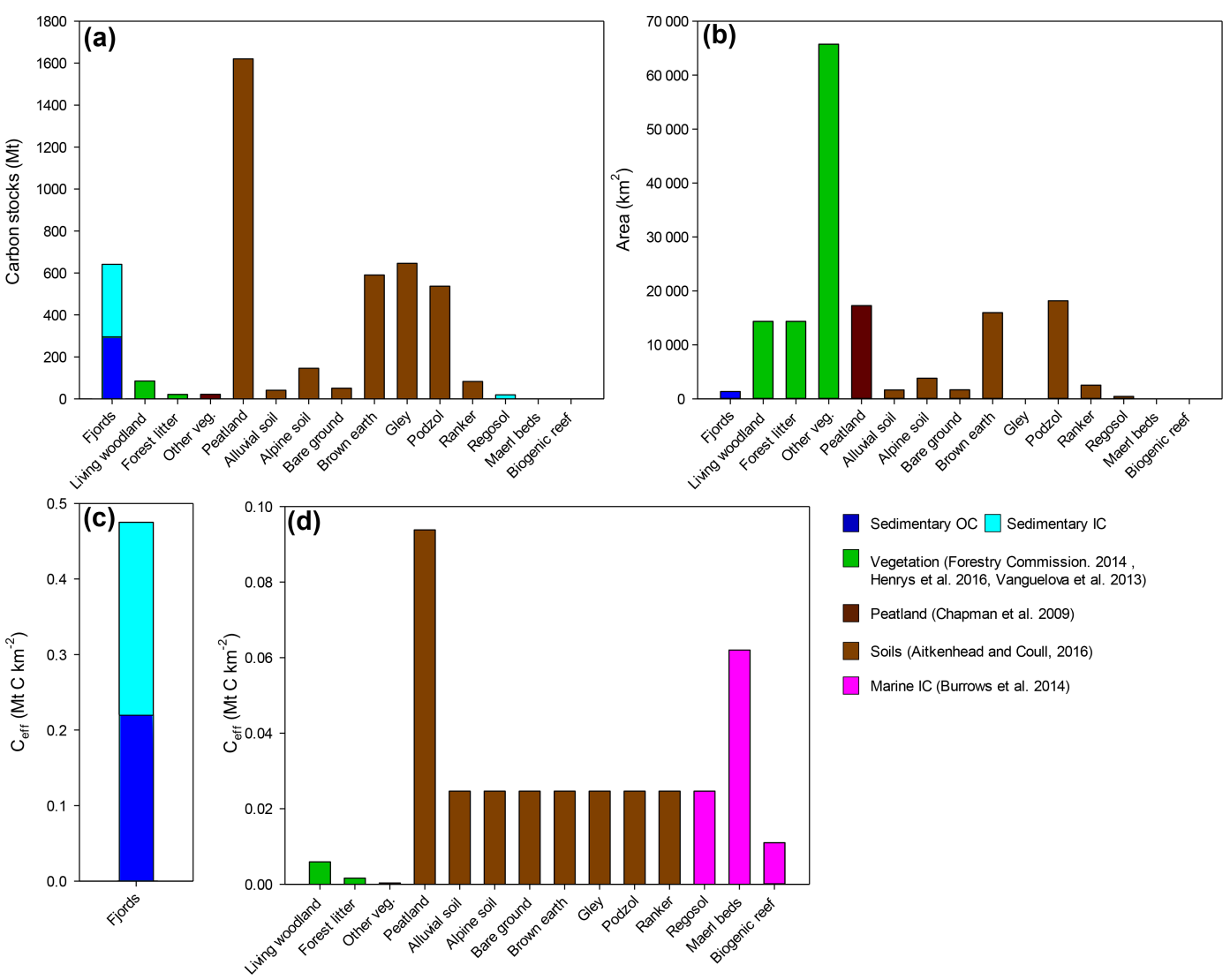

Figure 6. Comparison of Scotland's national fjordic sedimentary C store and other national inventories of C. (a) Carbon stocks (Mt), (b) area of storage $\left(\mathrm{km}^{2}\right)$ and (c) effective carbon storage $\left(\mathrm{MtC} \mathrm{km}^{-2}\right)$ for the 111 fjords. (d) Effective carbon storage $\left(\mathrm{MtC} \mathrm{km}^{-2}\right)$ for the other national $\mathrm{C}$ stores.

(i.e. the top $0.25 \mathrm{~m}$ ), the Thurøbund seagrass meadow is more effective at accumulating $\mathrm{C}$, although questions remain regarding the stability and longevity of these stores in comparison with the fjord sediments. This is a key concern when comparing $\mathrm{C}$ stores.

Radiocarbon dating (Nørgaard-Pedersen et al., 2006; Baltzer et al., 2010; Smeaton et al., 2016) shows that the fjords have been collecting sediment since the retreat of the last ice sheet (Clark et al., 2012), which results in these C stores likely being some of the oldest and most persistent in the UK. Of the terrestrial C stores, only soils and peatlands have the potential to store $\mathrm{C}$ over similar timescales, but they are significantly more vulnerable to natural and anthropogenic disturbance than the fjordic sediments. Vegetation and soil $\mathrm{C}$ stores are at risk from rapid and long-term environmental change. These environments can lose significant quantities of $\mathrm{C}$ through soil erosion (Cummins et al., 2011), fire (Davies et al., 2013) and vegetation change (Jackson et al., 2012); these are disturbances which are increasing in regularity and severity with growing climatic and anthropogenic pressure. When we consider the marine sedimentary $\mathrm{C}$ stores through the same prism of environmental change, it is evident that the restricted geomorphology, water depth and relative remoteness of these stores affords them a level of protection not found in the terrestrial environment. However, this does not imply that coastal sedimentary $\mathrm{C}$ stores do not require careful management. For example, the remobilisation of C-rich sediments at the sea floor from direct physical disturbance poses an increased risk to these effective longterm $\mathrm{C}$ stores. The recognition of these coastal habitats for both their biodiversity and additional ecosystem functioning, including $\mathrm{C}$ sequestration and storage, represents an important emerging opportunity to designate and help create a new thinking in the establishment of marine protected areas. Taking into account the areal extent of fjords, their proximity to terrestrial sources and their longevity and stability, we suggest that fjordic sediments are the most effective systems for the long-term storage of OC in the UK, and it is highly likely that fjords globally are just as effective as their mid-latitude equivalents at storing $\mathrm{C}$.

\section{Conclusions}

The sediments of mid-latitude fjords hold a significant quantity of $\mathrm{C}$ which has largely been overlooked in global $\mathrm{C}$ bud- 
gets and which constitute a significant component of natural capital for Scotland and the UK. Our results indicate that the $640.7 \pm 46 \mathrm{Mt}$ of $\mathrm{C}$ held within the sediments of these fjords is of similar if not greater magnitude than most terrestrial C stores. Fjords cover a small area in comparison with terrestrial C stores, but the stability and longevity of these coastal stores means that fjords are a highly effective longterm repository of $\mathrm{C}$ surpassing the Scottish peatlands, which have been the focus of intense research for decades. In contrast with their terrestrial equivalents, the magnitude of the fjord sedimentary $\mathrm{C}$ stores combined with their long-term stability emphasises the significant role that fjords and the coastal ocean more generally play in the burial and storage of $\mathrm{C}$ globally. This highlights the need for stronger international effort to quantify coastal sedimentary $\mathrm{C}$ stores and account for the $\mathrm{C}$ sequestration and associated climate-regulating services which these subtidal environments provide.

Data availability. No data sets were used in this article.

\section{The Supplement related to this article is available online at https://doi.org/10.5194/bg-14-5663-2017-supplement.}

Author contributions. CS and WENA conceived the research and wrote the paper, to which all co-authors contributed data or provided input. CS conducted the research as part of his $\mathrm{PhD}$ at the University of St Andrews, supervised by WENA, ALD and JAH.

Competing interests. The authors declare that they have no conflict of interest.

Acknowledgements. This work was supported by the Natural Environment Research Council (grant number NE/L501852/1) with additional support from the NERC Radiocarbon Facility (allocation 1934.1015). We thank the British Geological Survey (Edinburgh and Keyworth) for providing access to seismic profiles and access to sediment samples (loan number: 237389) and the crew and captain of RV Calanus for assisting in sample collection financially supported by the EU Framework V HOLSMEER project (EVK2-CT-2000-00060) and the EU FPVI Millennium project (contract number 017008). Further seismic profiles and the CALYPSO long core were acquired within the frame of the French ECLIPSE programme with additional financial support from NERC, SAMS and the University of St Andrews. The authors would like to thank Marion Dufresne Captain J. M. Lefevre and the Chief Operator Y. Balut (from IPEV). Additionally, we would like to thank Colin Abernethy and Richard Abel (Scottish Association of Marine Science) for laboratory support. Finally we would like to thank two anonymous reviewers whose insightful comments improved this paper.
Edited by: Caroline P. Slomp

Reviewed by: two anonymous referees

\section{References}

Aitkenhead, M. J. and Coull, M. C.: Mapping soil carbon stocks across Scotland using a neural network model, Geoderma, 262, 187-198, https://doi.org/10.1016/j.geoderma.2015.08.034, 2016.

Atamanchuk, D., Kononets, M., Thomas, P. J., Hovdenes, J., Tengberg, A., and Hall, P. O. J.: Continuous long-term observations of the carbonate system dynamics in the water column of a temperate fjord, J. Mar. Syst., 148, 272-284, https://doi.org/10.1016/j.jmarsys.2015.03.002, 2015.

Baltzer, A., Bates, R., Mokeddem, Z., Clet-Pellerin, M., WalterSimonnet, A.-V., Bonnot-Courtois, C., and Austin, W. E. N.: Using seismic facies and pollen analyses to evaluate climatically driven change in a Scottish sea loch (fjord) over the last $20 \mathrm{ka}$, Geol. Soc. London, Spec. Publ., 344, 355-369, https://doi.org/10.1144/SP344.24, 2010.

Bauer, J. E. and Bianchi, T. S.: Dissolved Organic Carbon Cycling and Transformation, Elsevier Inc., Treatise on Estuarine and Coastal Science, 5, 7-762012, 2011.

Bauer, J. E., Cai, W.-J., Raymond, P. A, Bianchi, T. S., Hopkinson, C. S., and Regnier, P. A. G.: The changing carbon cycle of the coastal ocean., Nature, 504, 61-70, https://doi.org/10.1038/nature12857, 2013.

Bianchi, T. S.: The role of terrestrially derived organic carbon in the coastal ocean: a changing paradigm and the priming effect, P. Natl. Acad. Sci. USA, 108, 19473-19481, https://doi.org/10.1073/pnas.1017982108, 2011.

Bianchi, T. S., Schreiner, K. M., Smith, R. W., Burdige, D. J., Woodard, S., and Conley, D. J.: Redox Effects on Organic Matter Storage in Coastal Sediments During the Holocene?: A Biomarker / Proxy Perspective, Annu. Rev. Earth Pl. Sc., 44, 295-319, https://doi.org/10.1146/annurev-earth-060614105417, 2016.

Bradley, R. I., Milne, R., Bell, J., Lilly, A., Jordan, C., and Higgins, A.: A soil carbon and land use database for the United Kingdom, Soil Use Manag., 21, 363-369, https://doi.org/10.1079/SUM2005351, 2005.

Brazier, V., Whittington, G., and Ballantyne, C. K.: Holocene debris cone evolution in glen etive Western Grampian Hhghlands, Scotland, Earth Surf. Proc. Land., 13, 525-531, 1988.

Burrows, M. T., Kamenos, N. A., Hughes D. J., Stahl, H., Howe, J. A., and Tett, P.: Assessment of carbon budgets and potential blue carbon stores in Scotland's coastal and marine environment. Scottish Natural Heritage Commissioned Report No. 761, available at: http://www.snh.org.uk/pdfs/publications/commissioned_ reports/761.pdf (last access: 8 August 2017), 2014.

Cage, A. G. and Austin, W. E. N.: Marine climate variability during the last millennium: The Loch Sunart record, Scotland, UK, Quaternary Sci. Rev., 29, 1633-1647, https://doi.org/10.1016/j.quascirev.2010.01.014, 2010.

Chapman, S. J., Bell, J., Donnelly, D., and Lilly, A.: Carbon stocks in Scottish peatlands, Soil Use Manag., 25, 105-112, https://doi.org/10.1111/j.1475-2743.2009.00219.x, 2009. 
Clark, C. D., Hughes, A. L. C., Greenwood, S. L., Jordan, C., and Petter, H.: Pattern and timing of retreat of the last British-Irish Ice Sheet, Quaternary Sci. Rev., 44, 112-146, https://doi.org/10.1016/j.quascirev.2010.07.019, 2012.

Cronin, J. R. and Tyler, I. D.: Organic carbon in a Scottish sea loch, in: Analytical Techniques in Environmental Chemistry, edited by: Albaiges, J., Pergamon Press, Oxford, 419-426, 1980.

Cui, X., Bianchi, T. S., Savage, C., and Smith, R. W.: Organic carbon burial in fjords: Terrestrial versus marine inputs, Earth Planet. Sc. Lett., 451, 41-50, https://doi.org/10.1016/j.epsl.2016.07.003, 2016.

Cummins, R., Donnelly, D., Nolan, A., Towers, W., Chapman, S., Grieve, I., and Birnie, R. V.: Peat erosion and the management of peatland habitats, Scottish Natural Heritage Commissioned Report No. 410, http://www.snh.org.uk/pdfs/publications/ commissioned_reports/410.pdf (last access: 8 August 2017), 2011.

Dadey, K. A., Janecek, T., and Klaus, A.: Dry bulk density: its use and determination, Proceedings of the Ocean Drilling Program, Scientific Results, 126, 551-554, 1992.

Davies, G. M., Gray, A., Rein, G., and Legg, C. J.: Peat consumption and carbon loss due to smouldering wildfire in a temperate peatland, For. Ecol. Manage., 308, 169-177, 2013.

Dix, J. K. and Duck, R. W.: A high-resolution seismic stratigraphy from a Scottish sea loch and its implications for Loch Lomond Stadial deglaciation, 15, 645-656, 2000.

Duarte, C. M., Middelburg, J. J., and Caraco, N.: Major role of marine vegetation on the oceanic carbon cycle, Biogeosciences, 2, 1-8, https://doi.org/10.5194/bg-2-1-2005, 2005.

Edwards, A. and Sharples, F.: Scottish Sea Lochs: A Catalogue, Scottish Marine Biological Association/Nature Conservancy Council, Oban, 1986.

Edwards, K. J. and Whittington, G.: Lateglacial palaeoenvironmental investigations at Wester Cartmore Farm, Fife and their significance for patterns of vegetation and climate change in eastcentral Scotland, Rev. Palaeobot. Palyno., 159, 14-34, 2010.

Forestry Commission: Carbon in living woodland trees in Britain: A National Forestry Inventory Report, available at: http://www. forestry.gov.uk/pdf/FCNFI113.pdf/\$FILE/FCNFI113.pdf, 2015.

Friedrich, J., Janssen, F., Aleynik, D., Bange, H. W., Boltacheva, N., Çagatay, M. N., Dale, A. W., Etiope, G., Erdem, Z., Geraga, M., Gilli, A., Gomoiu, M. T., Hall, P. O. J., Hansson, D., He, Y., Holtappels, M., Kirf, M. K., Kononets, M., Konovalov, S., Lichtschlag, A., Livingstone, D. M., Marinaro, G., Mazlumyan, S., Naeher, S., North, R. P., Papatheodorou, G., Pfannkuche, O., Prien, R., Rehder, G., Schubert, C. J., Soltwedel, T., Sommer, S., Stahl, H., Stanev, E. V., Teaca, A., Tengberg, A., Waldmann, C., Wehrli, B., and Wenzhöfer, F.: Investigating hypoxia in aquatic environments: diverse approaches to addressing a complex phenomenon, Biogeosciences, 11, 1215-1259, https://doi.org/10.5194/bg-11-1215-2014, 2014.

Gillibrand, P. A., Cage, A. G., and Austin, W. E. N.: A preliminary investigation of basin water response to climate forcing in a Scottish fjord: evaluating the influence of the NAO, Cont. Shelf Res., 25, 571-587, https://doi.org/10.1016/j.csr.2004.10.011, 2005.

Gillibrand, P. A., Cromey, C. J., Black, K. D., Inall, M. E., and Gontarek, S. J.: Identifying the risk of deoxygenation in Scottish sea lochs with isolated deep water, Scottish Aquaculture Research Forum, SARF 07 Report, 2006.
Golledge, N. R.: Glaciation of Scotland during the Younger Dryas stadial?: a review, J. Quat. Sci., 25, 550-566, https://doi.org/10.1002/jqs.1319, 2010.

Harris, D., Horwáth, W. R., and van Kessel, C.:, Acid fumigation of soils to remove carbonates prior to total organic carbon or carbon-13 isotopic analysis, Soil Sci. Soc. Am. J., 65, 18531856, 2001.

Henrys, P. A., Keith, A., and Wood, C. M.: Model estimates of aboveground carbon for Great Britain. NERC Environmental Information Data Centre, available at: https://doi.org/10.5285/9be652e7-d5ce-44c1-a5fc-8349f76f5f5c (last access: 10 August 2017), 2016.

Howe, J. A., Shimmield, T., Austin, W. E. N., and Longva, O.: Post-glacial depositional environments in a mid-high latitude glacially-overdeepened sea loch, inner Loch Etive, western Scotland, 185, 417-433, 2002.

Jackson, R. B., Banner, J. L., Jobbagy, E. G., Pockman, W. T., and Wall, D. H.: Ecosystem carbon loss with woody plant invasion of grasslands, Nature, 418, 623-626, 2012.

Khanna, N., Godbold, J. A., Austin, W. E. N., and Paterson, D. M.: The impact of ocean acidification on the functional morphology of foraminifera, PLoS One, 8, 10-13, https://doi.org/10.1371/journal.pone.0083118, 2013.

Lambeck, K.: Glacial rebound of the British Isles II. A high resolution high precsion model, Geophys. J. Int., 115, 960-990, 1993.

Loh, P. S., Miller, A. E. J., Reeves, A. D., Harvey, S. M., Overnell, J., and Systems, E.: Assessing the biodegradability of terrestrially-derived organic matter in Scottish sea loch sediments, 811-823, 2008.

Mastrandrea, M. D., Field, C. B., Stocker, T. F., Edenhofer, O., Ebi, K. L., Frame, D. J. Held, H., Kriegler, E., Mach, K. J., Matschoss, P. R., Plattner, G. K, Yohe, G. W., and Zwiers, F. W.: Guidance Note for Lead Authors of the IPCC Fifth Assessment Report on Consistent Treatment of Uncertainties, Intergovernmental Panel on Climate Change (IPCC), 2010.

McIntyre, K. L. and Howe, J. A.: Scottish west coast fjords since the last glaciation: a review, Geological Society, London, Special Publications, 344, 305-329, 2010.

Middelburg, J. J. and Levin, L. A.: Coastal hypoxia and sediment biogeochemistry, Biogeosciences, 6, 1273-1293, https://doi.org/10.5194/bg-6-1273-2009, 2009.

Middelburg, J. J., Vlug, T., Jaco, F., and van der Nat, W.: Organic matter mineralization in marine systems, Glob. Planet. Change, 8, 47-58, 1993.

Mokeddem, Z., Goubert, E., Lartaud, F., and Labourdette, N.: The "Turritella Layer": A Potential Proxy of a Drastic Holocene Environmental Change on the North - East Atlantic Coast, in: Sediment Fluxes in Coastal Areas, 3-21, https://link.springer.com/ chapter/10.1007/978-94-017-9260-8_1, 2015.

Nørgaard-Pedersen, N., Austin, W. E. N., Howe, J. A., and Shimmield, T.: The Holocene record of Loch Etive, western Scotland: Influence of catchment and relative sea level changes, Mar. Geol., 228, 55-71, https://doi.org/10.1016/j.margeo.2006.01.001, 2006.

Röhr, M. E., Boström, C., Canal-Vergés, P., and Holmer, M.: Blue carbon stocks in Baltic Sea eelgrass (Zostera marina) meadows, Biogeosciences, 13, 6139-6153, https://doi.org/10.5194/bg-136139-2016, 2016.

Russell, M., Robinson, C. D., Webster, L., Walsham, P., Phillips, L., Dalgarno, E., Rose, M., Watson, D., Scurfield, J., Avery, D. 
J., Devalla, S., Gubbins, M., Davies, I. M., and Moffat, C. F.: Persistent organic pollutants and trace metals in sediments close to Scottish marine fish farm, Scottish marine and freshwater science, 1, ISSN: 2043-7722, 2010.

Smeaton, C. and Austin, W. E. N.: Sources, sinks, and subsidies: Terrestrial carbon storage in mid-latitude fjords, J. Geophys. Res.-Biogeo., 122, https://doi.org/10.1002/2017JG003952, 2017.

Smeaton, C., Austin, W. E. N., Davies, A. L., Baltzer, A., Abell, R. E., and Howe, J. A.: Substantial stores of sedimentary carbon held in mid-latitude fjords, Biogeosciences, 13, 5771-5787, https://doi.org/10.5194/bg-13-5771-2016, 2016.

Smith, R. W., Bianchi, T. S., Allison, M., Savage, C., and Galy, V.: High rates of organic carbon burial in fjord sediments globally, Nat. Geosci., 8, 450-453, https://doi.org/10.1038/NGEO2421, 2015.

Stoker, M. and Bradwell, T.: Neotectonic deformation in a scottish fjord, Loch Broom, NW Scotland, Scot. J. Geol., 45, 107-116, 2009.

Stoker, M., Wilson, C. R., Howe J. A., Bradwell, T., and Long, D.: Paraglacial slope instability in Scottish fjords: Examples from Little Loch Broom, NW Scotland, Geological Society Special Publications, 344, 225-242, 2010

Syvitski, J. P. M. and Shaw, J.: Sedimentology and Geomorphology of Fjords, Geomorphology and Sedimentology of Estuaries, Dev. Sedimentology, 53, 113-178, 1995.

Syvitski, J. P. M., Burrell, D. C., and Skei, J. M.: Fjords, Processes and Products, Springer-Verlag, New York, 1987. van der Heijden, L. H. and Kamenos, N. A.: Reviews and syntheses: Calculating the global contribution of coralline algae to total carbon burial, Biogeosciences, 12, 6429-6441, https://doi.org/10.5194/bg-12-6429-2015, 2015.

Vanguelova, E. I., Nisbet, T. R., Moffat, A. J., Broadmeadow, S., Sanders, T. G. M., and Morison, J. I. L.: A new evaluation of carbon stocks in British forest soils, Soil Use Manag., 29, 169181, https://doi.org/10.1111/sum.12025, 2013.

Verardo, D. J., Froelich, P. N., and McIntyre, A.: Determination of organic carbon and nitrogen in marine sediments using the Carlo Erba NA-1500 Analyzer, Deep-Sea Res., 37, 157-165, 1990.

Webster, L., Fryer, R. J., Megginson, C., Dalgarno, E. J., Mcintosh, A. D., Moffat, C. F., Road, V., and Ab, U. K.: The polycyclic aromatic hydrocarbon and geochemical biomarker composition of sediments from sea lochs on the west coast of Scotland, J. Environ. Monit., 6, 219-228, 2004.

Woulds, C., Cowie, G. L., Levin, L. A., Andersson, J. H., Middelburg, J. J., Vandewiele, S., Lamont, P. A., Larkin, K. E., Gooday, A. J., Schumacher, S., Whitcraft, C., and Jeffreys, R. M.: Oxygen as a control on seafloor biological communities and their roles in sedimentary carbon cycling, Limnol. Oceanogr., 52, 1-13, 2007.

Woulds, C., Bouillon, S., Cowie, G. L., Drake, E., Middelburg, J. J., and Witte, U.: Patterns of carbon processing at the seafloor: the role of faunal and microbial communities in moderating carbon flows, Biogeosciences, 13, 4343-4357, https://doi.org/10.5194/bg-13-4343-2016, 2016. 